\title{
Coconut genome size determined by flow cytometry: Tall versus Dwarf types
}

\author{
M. Freitas Neto', T.N.S. Pereira1, I.G.C. Geronimo', A.O.N. Azevedo', \\ S.R.R. Ramos ${ }^{2}$ and M.G. Pereira ${ }^{1}$ \\ ${ }^{1}$ Laboratório de Melhoramento Genético Vegetal, \\ Centro de Ciências e Tecnologias Agropecuárias, \\ Universidade Estadual do Norte Fluminense Darcy Ribeiro, \\ Campos dos Goytacazes, RJ, Brasil \\ ${ }^{2}$ Embrapa/CPATC, Aracaju, SE, Brasil \\ Corresponding author: T.N.S. Pereira \\ E-mail: telmasp2012@gmail.com \\ Genet. Mol. Res. 15 (1): gmr.15017470 \\ Received August 18, 2015 \\ Accepted October 19, 2015 \\ Published February 5, 2016 \\ DOI http://dx.doi.org/10.4238/gmr.15017470
}

ABSTRACT. Coconuts (Cocos nucifera L.) are tropical palm trees that are classified into Tall and Dwarf types based on height, and both types are diploid $(2 n=2 x=32$ chromosomes). The reproduction mode is autogamous for Dwarf types and allogamous for Tall types. One hypothesis for the origin of the Dwarf coconut suggests that it is a Tall variant that resulted from either mutation or inbreeding, and differences in genome size between the two types would support this hypothesis. In this study, we estimated the genome sizes of 14 coconut accessions (eight Tall and six Dwarf types) using flow cytometry. Nuclei were extracted from leaf discs and stained with propidium iodide, and Pisum sativum ( $2 \mathrm{C}=9.07 \mathrm{pg}$ DNA) was used as an internal standard. Histograms with good resolution and low coefficients of variation (2.5 to $3.2 \%$ ) were obtained. The $2 \mathrm{C}$ DNA content ranged from 5.72 to $5.48 \mathrm{pg}$ for Tall accessions and from 5.58 to $5.52 \mathrm{pg}$ for Dwarf accessions. The mean genome sizes for Tall and Dwarf specimens were 5.59 and $5.55 \mathrm{pg}$, respectively. Among all accessions, Rennel Island Tall had the highest mean DNA content $(5.72 \mathrm{pg})$, whereas West African Tall had the lowest $(5.48 \mathrm{pg})$. The mean coconut genome size $(2 \mathrm{C}=5.57 \mathrm{pg}$, 
corresponding to $2723.73 \mathrm{Mbp} /$ haploid set) was classified as small. Only small differences in genome size existed among the coconut accessions, suggesting that the Dwarf type did not evolve from the Tall type.

Key words: Cocos nucifera L.; DNA content; C-value; Coconut accessions; Palm tree

\section{INTRODUCTION}

The coconut (Cocos nucifera L.) is a diploid palm species with $2 n=2 x=32$ chromosomes. This seed-propagated, slow-growing tree occurs naturally throughout the tropics between $20^{\circ} \mathrm{N}$ and $20^{\circ} \mathrm{S}$ latitude (Batugal et al., 2009), and it is considered the most economically important tropical species (Persley, 1992). Coconuts comprise two main types: Tall and Dwarf (Purseglove, 1975). Tall coconuts are characterized by heights up to $30 \mathrm{~m}$, and they are predominantly allogamous with medium- to large-sized fruits. The variety can produce 60 to 80 fruits $\cdot$ tree $^{-1}$. year $^{-1}$ that are harvested 11 to 12 months after flowering. Moreover, the Tall coconut ecotypes are named according to the geographic region or country in which they evolved.

Dwarf coconuts are autogamous, and flowering is initiated after an average of 3 years. The

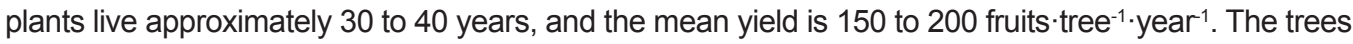
are smaller than Tall coconut trees, reaching a height of 10 to $12 \mathrm{~m}$, and the fruits are smaller. Dwarf coconuts are classified into three groups based on fruit color: green, yellow, and red (Harries, 1978).

The origin and dispersal history of coconuts is still controversial (Clement et al., 2013; Baudouin et al., 2014; Harries and Clement, 2014). Several hypotheses have been developed to explain the origin of Dwarf coconuts, and one hypothesis suggests that the Dwarf type is a variant of the Tall coconut that resulted from either mutation or inbreeding (Swaminathan and Nambiar, 1961). Several authors have observed only minor differences between the karyotypes of the two coconut types, but the results do not support the idea that the Dwarf type evolved from the Tall type (Raveendranath and Ninan, 1973; Sisunandar and Adkins, 2007).

The estimation of genome size based on DNA content is important for genomic characterization. Moreover, this estimation is not only important for genetic improvement (Leus et al., 2009), cell biology, systematic biology, and taxonomy research (Loureiro, 2007), but also for evolutionary studies (Baack et al., 2005). To date, few studies have estimated the DNA content in coconuts via flow cytometry, and to our knowledge, none have compared the genome sizes between Dwarf and Tall types. In this study, flow cytometry was used to estimate the genome size of 14 coconut genotypes (eight Tall and six Dwarf types) to determine whether there are genome size differences that support the theory that the Dwarf type evolved from the Tall type.

\section{MATERIAL AND METHODS}

\section{Plant material}

Leaf samples from 14 coconut accessions (six Dwarf and eight Tall accessions) were used to analyze DNA content. These accessions are maintained in the Active Germplasm Bank of Coconut, a living collection grown at Embrapa Tabuleiros Costeiros, Aracajú, Sergipe, Brazil. The analyses were performed at the Laboratory of Plant Breeding, Universidade Estadual do Norte Fluminense Darcy Ribeiro, located in Campos dos Goytacazes, Rio de Janeiro, Brazil. 


\section{Flow cytometry analysis}

Leaf samples were collected from adult plants, packed, transported to the laboratory, and stored in a refrigerator for up to $48 \mathrm{~h}$. To prepare samples for cytometer readings, leaf discs (approximately 0.5 $\mathrm{cm}^{2}$ ) of each accession were used to extract nuclei (Galbraith et al., 1983; Otto, 1990). The leaf samples were placed in $500 \mu \mathrm{L}$ extraction buffer (CyStain UV Precise P, Partec GmbH, Münster, Germany) on Petri dishes, and they were chopped with a blade for $90 \mathrm{~s}$ at $25^{\circ} \mathrm{C}$ to suspend nuclei.

The samples were filtered through $50-\mathrm{mm}$ membranes, and $2 \mathrm{~mL}$ staining solution (CyStain UV Precise P, Partec $\mathrm{GmbH}$ ) containing propidium iodide and RNase was added to each tube. The tubes were then incubated at $4^{\circ} \mathrm{C}$ for $30 \mathrm{~min}$. The same procedure was performed with Pisum sativum leaflets $(2 \mathrm{C}=9.07 \mathrm{pg})$, which had been defined as the best internal standard at a preliminary stage. Samples containing the suspended nuclei of each coconut accession and the internal standard were prepared together for further analysis.

After adjusting the equipment, the samples were analyzed with a flow cytometer (Partec PA II; Partec $\mathrm{GmbH}$ ). Five readings (replicates) per accession were prepared, and 10,000 nuclei were counted per analysis. Data were collected and mean peak analyses were performed using the Flowmax software (Partec $\mathrm{GmbH})$.

Genome size was calculated (Doležel and Bartos, 2005), and the data were tested by ANOVA. The mean values of the accessions were grouped, based on the Scott and Knott test results at $5 \%$ probability, using the Genes statistical package (Cruz, 2006). The genome size in megabase pairs (Mbp) was estimated using the conversion factor 1 pg = $978 \mathrm{Mbp}$ (Doležel et al., 2003).

\section{RESULTS}

The DNA content differed significantly among the coconut accessions $(P<0.01)$. Of the 14 accessions studied, the highest DNA content was observed in Rennel Island Tall (5.72 pg/2C or $2.86 \mathrm{pg} / \mathrm{C}$ ), and the smallest value was found in West African Tall (5.48 pg/2C or $2.74 \mathrm{pg} / \mathrm{C})$. The coconut accessions formed four groups based on their 2C DNA content (Table 1). High-resolution histograms (Figures 1 and 2) were obtained for all samples, and the coefficients of variation (CVs) ranged from 2.5 to $3.2 \%$ (Table 1 ).

Table 1. Mean genome size of coconut accessions estimated in picograms (pg), in megabase pairs (Mbp), and the coefficient of variation (CV).

\begin{tabular}{|c|c|c|c|c|}
\hline \multirow[t]{2}{*}{ Coconut accessions } & \multirow[t]{2}{*}{ Symbol } & \multicolumn{3}{|c|}{ Genome size } \\
\hline & & $\mathrm{pg} / 2 \mathrm{C}$ & CV (\%) & Mbp/haploid set \\
\hline Rennel Island Tall & RIT & $5.72 \mathrm{a}$ & 3.1 & 2797.08 \\
\hline Polynesian Tall & PT & $5.68 \mathrm{~b}$ & 2.8 & 2777.52 \\
\hline Rotuma Tall & RT & $5.66 \mathrm{~b}$ & 3.2 & 2767.74 \\
\hline Praia do Forte Tall & PFT & $5.60 \mathrm{c}$ & 3.2 & 2738.40 \\
\hline Vanuatu Tall & VT & $5.54 \mathrm{c}$ & 2.7 & 2709.06 \\
\hline Tonga Tall & TT & $5.54 \mathrm{c}$ & 3.0 & 2650.38 \\
\hline Malayan Tall & MT & $5.50 \mathrm{~d}$ & 2.9 & 2689.50 \\
\hline West African Tall & WAT & $5.48 \mathrm{~d}$ & 2.9 & 2679.72 \\
\hline Mean Tall & - & 5.59 & - & 2733.51 \\
\hline Gramame Red Dwarf & GRD & $5.58 \mathrm{c}$ & 2.7 & 2728.62 \\
\hline Gramame Yellow Dwarf & GYD & $5.56 \mathrm{c}$ & 2.8 & 2718.84 \\
\hline Malayan Yellow Dwarf & MYD & $5.56 \mathrm{c}$ & 2.5 & 2718.84 \\
\hline Malayan Red Dwarf & MRD & $5.56 \mathrm{c}$ & 2.8 & 2718.84 \\
\hline Cameroon Red Dwarf & CRD & $5.54 \mathrm{c}$ & 3.0 & 2709.06 \\
\hline Jiqui Green Dwarf & JGD & $5.52 \mathrm{~d}$ & 2.5 & 2699.28 \\
\hline Mean Dwarf & - & 5.55 & - & 2713.95 \\
\hline Overall mean & - & 5.57 & - & 2723.73 \\
\hline
\end{tabular}



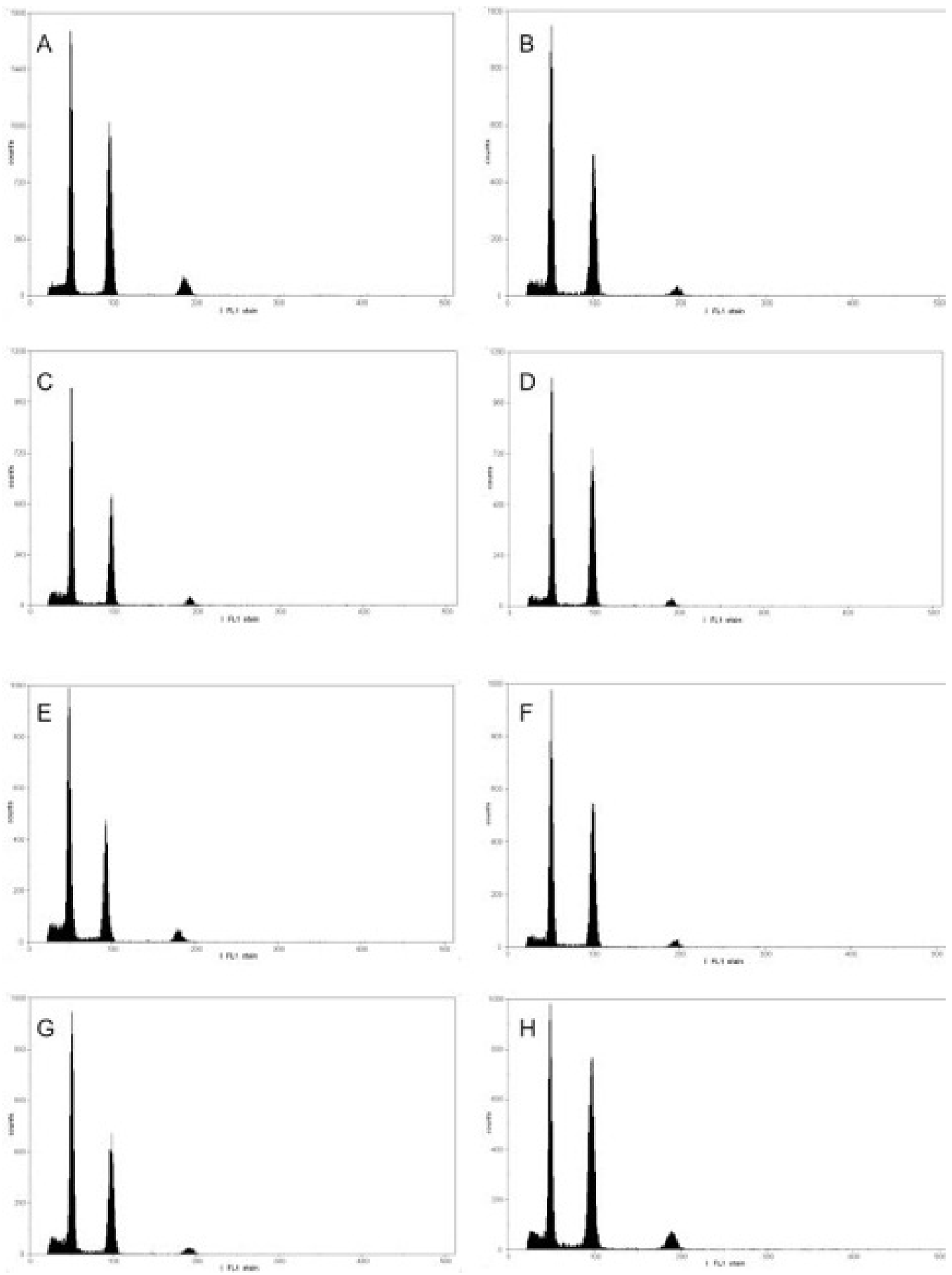

Figure 1. Flow cytometry histograms of Tall accessions. The first peak represents the Tall accession, and the second peak represents the internal standard (Pisum sativum L.). A. PFT; B. MT; C. WAT; D. PT; E. RIT; F. RT; G. TT; H. VT. 

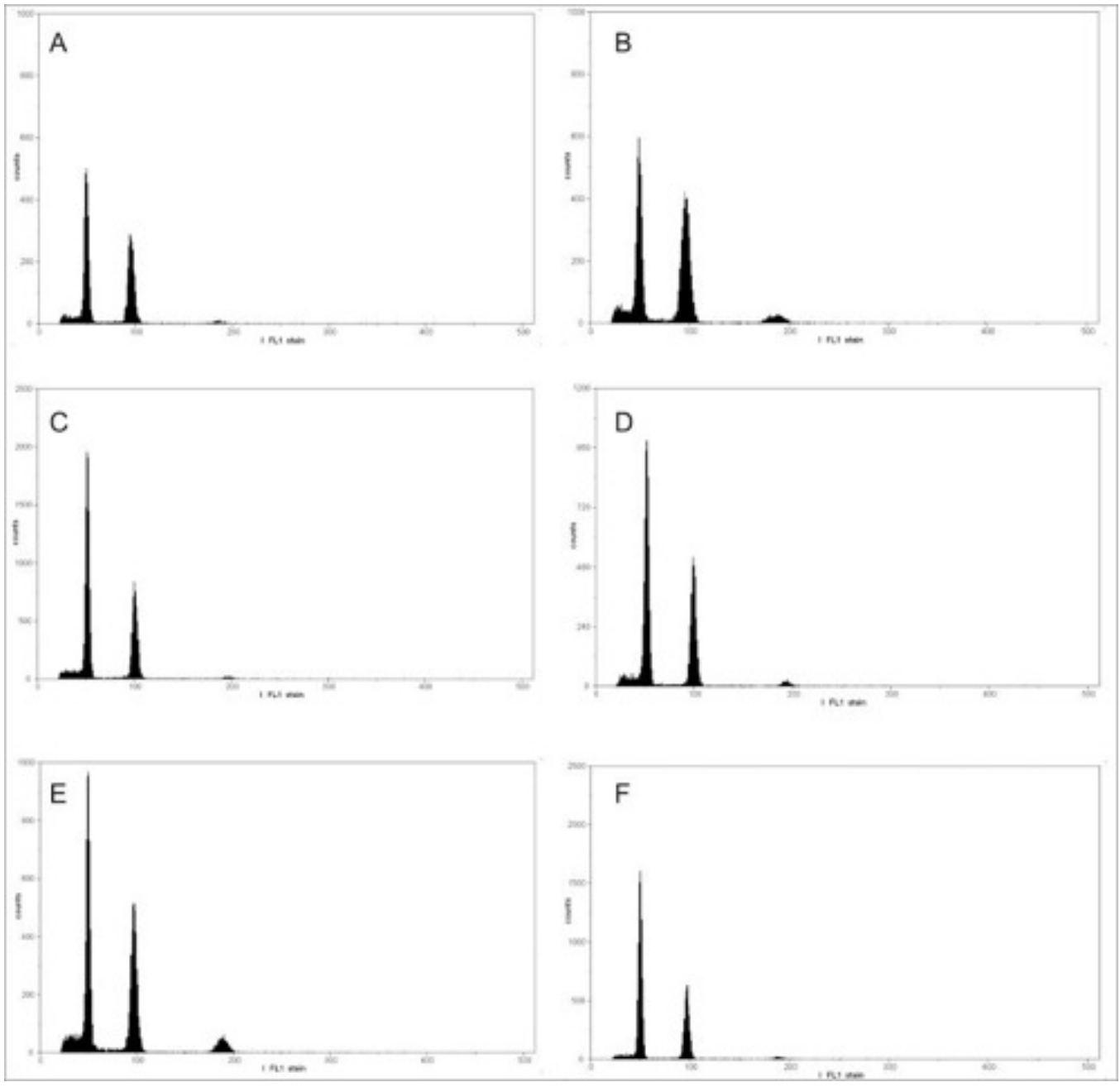

Figure 2. Flow cytometry histograms of Dwarf accessions. The first peak represents the Dwarf accession, and the second peak represents the internal standard (Pisum sativum L.). A. MRD; B. JGD; C. GYD; D. GRD; E. MYD; F. RCD.

The mean DNA content for Tall accessions was $5.59 \mathrm{pg} / 2 \mathrm{C}$, corresponding to $5.47 \mathrm{~Gb} / 2 \mathrm{C}$ and $2733.51 \mathrm{Mbp} / 1 \mathrm{C}$. Among the Dwarf accessions, Red Dwarf from Gramame, Brazil, had the highest DNA content (5.58 pg/2C), and Green Dwarf from Jiqui, Brazil, had the lowest (5.52 pg/2C). The 2C DNA content showed greater variation among the Tall group than among the Dwarf group (Table 1). The Dwarf accessions had low intra-group variation with non-significant differences, with the exception of Green Dwarf from Jequi, Brazil.

\section{DISCUSSION}

Few studies have determined DNA content via flow cytometry in Arecaceae species. In our study, the mean 2C DNA content for coconuts was 5.59 and $5.55 \mathrm{pg}$ for Tall and Dwarf 
accessions, respectively. One of the first studies of DNA content in palm trees estimated a $2 \mathrm{C}$ value of $7.10 \mathrm{pg}$ for coconuts using Feulgen densitometry (Röser et al., 1997). DNA content is generally estimated based on nuclei extracted from fresh, young leaves (Doležel and Bartos, 2005). Coconut germplasm is maintained in vitro or in vivo, and in the few coconut studies using cytometry, nuclei were extracted from plants grown in vitro. In this study, nuclei were extracted from the mature leaves of trees that were stored in a coconut germplasm collection. Nuclear suspension quality is judged based on analyses of histograms depicting the relative DNA content. The histogram should contain minimal amounts of background debris, and the variation should be low (Doležel and Bartos, 2005). The variation is usually expressed as the CV, and CV values in our study varied from 2.5 to $3.0 \%$. Moreover, high-quality analyses exhibited CV values of 1.0 to $2.0 \%$, and routine analyses showed CV values of approximately 3.0\% (Marie and Brown, 1993). However, CV values below 5.0\% were considered satisfactory (Galbraith et al., 2002), and the authors also stated that in some recalcitrant species, such as coconuts, the recommended CV values are difficult to obtain.

The mean 2C DNA content of the Tall group was $5.59 \mathrm{pg}$, which corresponded to 5467.02 Mbp (Doležel et al., 2003), and this was higher than the mean of the Dwarf accessions (5.55 pg). In Lathyrus, 2C DNA values were higher for outbreeding perennials and lower for inbreeding annuals (Rees and Hazarika, 1967). In this study, we observed that there was greater variation in 2C DNA values among allogamous and perennial Tall types than among autogamous Dwarf types.

The mean 2C DNA content for the Dwarf group was $5.55 \mathrm{pg}$, which corresponded to $5427.9 \mathrm{Mbp}$ (Doležel et al., 2003). A DNA content value of $5.60 \mathrm{pg} / 2 \mathrm{C}$ was estimated for Malayan Yellow Dwarf, which was similar to the value found in this study $(2 \mathrm{C}=5.55 \mathrm{pg}$ ) (Sandoval et al. $2003)$ even though the authors used Hordeum vulgare $(2 \mathrm{C}=11.12 \mathrm{pg})$ and Petunia hybrida $(2 \mathrm{C}$ $=2.85 \mathrm{pg}$ ) as internal reference standards. The internal reference standard should ideally have a similar, but not overlapping, genome size compared to the species under study (Doležel and Bartos, 2005). Arabidopsis thaliana, Solanum esculentum, and $P$. sativum were indicated as the most appropriate internal reference standards (Praça-Fontes et al., 2011).

The Dwarf accessions showed little variation of 2C DNA content, indicating that this coconut group is more homogenous than the Tall group. Genetic divergence was investigated among Dwarf genotypes, and the results indicated that Green Dwarf is most similar to Cameroon Red Dwarf and most distant from Malayan Yellow Dwarf (Cambuí et al., 2007). In this study, the DNA content of Green Dwarf differed from that of all other Yellow or Red Dwarf varieties, but there were no significant differences in DNA content between Yellow and Red Dwarfs. A study based on RAPD analyses showed that Red Dwarfs are genetically distinct from the Green and Yellow Dwarfs (Daher et al., 2002). Moreover, the Red, Yellow, and Green Dwarf varieties differ mainly in their fruit color, which is determined by two loci ( $R$ and $G)$. The genotypes of Yellow, Red, and Green Dwarfs are rrgg, R-gg, and rrG-, respectively (Bourdeix, 1988). Thus, large differences in DNA content among the Red, Green, and Yellow Dwarf varieties were not expected.

The mean 2C DNA content of coconut species was $5.57 \mathrm{pg} / 2 \mathrm{C}$, corresponding to 5447.46 Mbp (Doležel et al., 2003). The value calculated in this study was slightly different from values reported for other Arecaceae species (Bharathan et al., 1994; Rival et al., 1997). The first study of Arecaceae was carried out using Feulgen densitometry to investigate 83 species that represented 53 genera, and the 2C DNA content ranged from $1.90 \mathrm{pg}$ in a diploid species (Phytelephas aequarorialis Spruce) to $78.20 \mathrm{pg}$ in a species with a high polyploidy level (38x) (Voanioala gerardii J. Dransf.) (Röser et al., 1997). Recent studies using flow cytometry have reported 2C values of $17.50 \mathrm{pg}$ for Trithrinax campestris, which is considered high for palm trees (Gaiero et al., 2012), and $5.80 \mathrm{pg}$ for Acrocomia aculeata (Abreu et al., 2011), which is comparable to the results of 
this study. The $2 \mathrm{C}$ content was reported for Elaeis species, and it ranged from 3.64 to $4.10 \mathrm{pg}$ (Madon et al., 2008). However, values higher than $8.00 \mathrm{pg}$ (8.70 to $9.41 \mathrm{pg}$ ) were reported for three Euterpe species (Oliveira, 2011), and the DNA content ranged between 6.46 and $6.96 \mathrm{pg}$ in five Oenocarpus species (Oliveira, 2012).

Based on the results, one might conclude that the coconut genome is small $(5.57 \mathrm{pg} / 2 \mathrm{C}$ and 2723.73 Mbp/per haploid set). Leitch et al. (1998) defined species with C-values and genome sizes $\leq 1.40$ and $\leq 3.50 \mathrm{pg}$ as having very small and small genomes, respectively. Similarly, species with C-values and genome sizes $\geq 14.0$ and $\geq 35.0 \mathrm{pg}$ were defined as having large and very large genomes, respectively. A preliminary study estimated the coconut genome size at $2.6 \mathrm{~Gb}$ using the HiSeq technique (Alsaihati et al., 2014).

C-values often decrease during evolution, but more research is required to identify the molecular events that are involved (Bennett et al., 2000). Arecaceae have chromosome numbers ranging from $2 n=26$ to $2 n=36$ (Swaminathan and Nambiar, 1961; Sisunandar and Adkins, 2007). In palms, karyotype evolution has involved a reduction in the number of chromosomes from the ancestral value $(2 n=36)$ via disploidy or aneuploidy (Röser, 1994), and this is evident in coconut varieties, which are now diploid $(2 n=2 x=32)$.

Although the Tall and Dwarf coconut types differed in terms of their height and mode of reproduction, there were very small differences in their genome sizes (5.59 pg for Tall types and $5.55 \mathrm{pg}$ for Dwarf types on average). Therefore, these results do not support the theory that Dwarf types evolved from Tall types, because the genome size is a quantitative species characteristic that is relatively consistent among individuals within a population (Greilhuber, 1998). This is the first report regarding the genome sizes of Tall and Dwarf coconut accessions, and this information may be useful for research on breeding, germplasm characterization, and genome sequencing.

\section{Conflicts of interest}

The authors declare no conflict of interest.

\section{ACKNOWLEDGMENTS}

The authors thank Fundação Carlos Chagas Filho de Amparo à Pesquisa do Estado do Rio de Janeiro (FAPERJ) for financial support.

\section{REFERENCES}

Abreu IS, Carvalho CR, Carvalho GMA and Motoike SY (2011). First karyotype, DNA C-value and AT/GC base composition of macaw palm (Acrocomia aculeata, Arecaceae) - a promising plant for biodiesel production. Aust. J. Bot. 59: 149-155. http://dx.doi.org/10.1071/BT10245

Alsaihati B, Liu W, Lin Q and Al-Mssallem IS (2014). Coconut genome de novo sequencing. XXII Conference of Plant and Animal Genome. San Diego, CA. Available at [http://www.intpag.org]. Accessed May 2015.

Baack EJ, Whitney KD and Rieseberg LH (2005). Hybridization and genome size evolution: timing and magnitude of nuclear DNA content increases in Helianthus homoploid hybrid species. New Phytol. 167: 623-630. http://dx.doi.org/10.1111/j.1469-8137.2005.01433.x

Batugal PA, Bourdeix R and Baudouin L (2009). Breeding plantation tree crops: tropical species. In: Coconut breeding (Mohan JAS and Priyadarsham PM, eds.). Springer, New York, 327-375.

Baudouin L, Gunn BF and Olsen KM (2014). The presence of coconut in southern Panama in pre-Columbian times: clearing up the confusion. Ann. Bot. 113: 1-5. http://dx.doi.org/10.1093/aob/mct244

Bennett MD, Bhandol P and Leitch IJ (2000). Nuclear DNA amounts in Angiosperms and their modern uses-807 new estimates. Ann. Bot. 86: 859-909. http://dx.doi.org/10.1006/anbo.2000.1253 
Bharathan G, Lambert G and Galbraith DW (1994). Nuclear DNA content of monocotyledons and related taxa. Am. J. Bot. 81: 381-386. http://dx.doi.org/10.2307/2445466

Bourdeix R (1988). Genetic determinism in Dwarf coconut germ colour. Oléagineux 43: 373-374.

Cambui EVF, Aragão WM and Leal MLS (2007). Variabilidade genética entre cultivares de coqueiro anão (Cocos nucifera, L.). Rev. Bras. Biocienc. 5: 165-167.

Clement CR, Zizumbo-Villarreal D, Brown CH, Ward RG, et al. (2013). Coconuts in the Americas. Bot. Rev. 79: 342-370. http://dx.doi.org/10.1007/s12229-013-9121-z

Cruz CD (2006). Programa Genes versão Windows: aplicativo computacional em genética e estatística. Editora UFV, Viçosa.

Daher RF, Pereira MG, Tupinambá EA, Amaral Junior AT, et al. (2002). Assessment of coconut tree genetic divergence by compound sample RAPD marker analysis. Crop Breed. Appl. Biot. 2: 431-438. http://dx.doi.org/10.12702/1984-7033.v02n03a14

Doležel J and Bartos J (2005). Plant DNA flow cytometry and estimation of nuclear genome size. Ann. Bot. 95: 99-110. http://dx.doi.org/10.1093/aob/mci005

Doležel J, Bartos J, Voglmar H and Greilhuber J (2003). Nuclear DNA content and genome size in trout and human. Cytometry A 51: 127-128.

Gaiero P, Mazzella C, Vaio M, Barros e Silva AE, et al. (2012). An unusually high heterochromatin content and large genome size in the palm tree Trithrinax campestris (Arecaceae). Aust. J. Bot. 60: 378-382. http://dx.doi.org/10.1071/BT12029

Galbraith DW, Harkins KR, Maddox JM, Ayres NM, et al. (1983). Rapid flow cytometric analysis of the cell-cycle in intact planttissues. Science 220: 1049-1051. http://dx.doi.org/10.1126/science.220.4601.1049

Galbraith DW, Lambert G, Macas J and Doležel J (2002). Current protocols in cytometry. In: Analysis of nuclear DNA content and ploidy in higher plants (Robinson J, Azmi A and Tutois S, eds.). John Wiley \& Sons, Inc., New York.

Greilhuber J (1998). Intraspecific variation in genome size: a critical reassessment. Ann. Bot. 82: 27-35. http://dx.doi.org/10.1006/anbo.1998.0725

Harries HC (1978). The evolution, dissemination and classification of Cocos nucifera. Bot. Rev. 44: 265-319. http://dx.doi.org/10.1007/BF02957852

Harries HC and Clement CR (2014). Long-distance dispersal of the coconut palm by migration within the coral atoll ecosystem. Ann. Bot. 113: 565-570. http://dx.doi.org/10.1093/aob/mct293

Leitch IJ, Chase MW and Bennett MD (1998). Phylogenetic analysis of DNA C-values provides evidence for a small ancestral genome size in flowering plants. Ann. Bot. 82: 85-94. http://dx.doi.org/10.1006/anbo.1998.0783

Leus L, Van Laere K, Dewitte A and Van Huylenbroeck J (2009). Flow cytometry for plant breeding. Acta Hort. 836: 221-226. http://dx.doi.org/10.17660/ActaHortic.2009.836.31

Loureiro JCM (2007). Aplicação da citometria de fluxo ao estudo do genoma vegetal. Master's thesis, Universidade de Aveiro, Aveiro.

Madon M, Phoon LQ, Clyde MM and Mohd Din A (2008). Application of flow cytometry for estimation of DNA nuclear content Elaeis. J. Oil Palm Res. 20: 447-452.

Marie D and Brown S (1993). A cytrometric exercise in plant DNA histograms, with 2C values for 70 species. Biol. Cell 78: 4151. http://dx.doi.org/10.1016/0248-4900(93)90113-S

Oliveira LC (2011). Palinologia, citogenética e conteúdo de DNA nuclear em espécies do gênero Euterpe. Master's thesis, UFLA, Lavras.

Oliveira NP (2012). Estudos polínicos, citogenética e quantidade de DNA nuclear em espécies do gênero Oenocarpus (Arecaceae). Master's thesis, UFLA, Lavras.

Otto FJ (1990). Methods in cell biology. In: DAPI staining of ðxed cells for high-resolution ñow cytometry of nuclear DNA (Darzynkiewickz Z and Crissman HA, eds.). Academic Press, San Diego, 105110.

Persley GJ (1992). Replanting the tree of life: toward an international agenda for coconut palm research. CAB/ACIAR, Wallingford.

Praça-Fontes MM, Carvalho CR, Clarindo WR and Cruz CD (2011). Revisiting the DNA C-values of the genome size-standards used in plant flow cytometry to choose the "best primary standards". Plant Cell Rep. 30: 1183-1191. http://dx.doi.org/10.1007/s00299-011-1026-x

Purseglove JW (1975). Tropical crops - monocotyledons. Longman, London.

Raveendranath TG and Ninan CA (1973). A study of somatic chromosome complements of Tall and Dwarf coconuts and its bearing on inter varietal variation and evolution of coconuts. J. Plantation Crops 1: 17-22.

Rees H and Hazarika H (1967). Chromosome today. In: Chromosome evolution in Lathyrus. (Darlington CD and Lewis KR, eds.). Plenum Press, New York, 158-165.

Rival A, Beule T, Barre P, Hamon S, et al. (1997). Comparative flow cytometric estimation of nuclear DNA content in oil palm (Elaeis guineensis Jacq.) tissue cultures and seed-derived plants. Plant Cell Rep. 16: 884-887 http://dx.doi.org/10.1007/s002990050339 
Röser M (1994). Pathways of karyological differentiation in palms (Arecaceae). Plant Syst. Evol. 189: 83-122. http://dx.doi.org/10.1007/BF00937580

Röser M, Johson MAT and Hanson L (1997). Nuclear DNA amounts in palms (Arecaceae). Bot. Acta 110: 79-89. http://dx.doi.org/10.1111/j.1438-8677.1997.tb00614.x

Sandoval A, Hocher VE and Verdeil JL (2003). Flow cytometric analysis of the cell cycle in different coconut palm (Cocos nucifera L.) tissues cultured in vitro. Plant Cell Rep. 22: 25-31. http://dx.doi.org/10.1007/s00299-003-0651-4

Sisunandar RA and Adkins SW (2007). Karyotype of some Indonesian coconut (Cocos nucifera) cultivars. Chromosome Res. 15: 36-37.

Swaminathan MS and Nambiar MC (1961). Cytology and origin of the dwarf coconut palm. Nature 192: 85-86. http://dx.doi.org/10.1038/192085a0 